\title{
Problem budżetu \\ obywatelskiego
}

\author{
Eugeniusz Wojciechowski \\ Prof. zw. dr hab., Uniwersytet Łódzki, \\ Wydział Ekonomiczno-Socjologiczny, \\ Katedra Gospodarki Samorządu Terytorialnego \\ http://dx.doi.org/10.18778/8088-114-3.22
}

\section{Wprowadzenie}

Ostatnio popularny stał się tzw. budżet obywatelski, zwany też partycypacyjnym. Obserwacja poczynań związanych z jego wdrażaniem w życie rodzi pytanie, czy jest to konieczność czy moda? Jego celem jest bezpośrednie zaangażowanie mieszkańców w proces podejmowania decyzji dotyczących wyboru zakresu zadań publicznych, w ramach wyznaczonej puli środków budżetowych i przejęcia części odpowiedzialności. Jest to słuszna idea, zachęcająca do aktywności społecznej w rozwoju lokalnym, ale śledzenie dotychczasowego przebiegu działań skłania do pewnych krytycznych ocen.

Treścią rozważań podjętych w artykule jest próba analizy i oceny budżetu obywatelskiego w kontekście efektywności gospodarowania środkami publicznymi. Celem artykułu jest ukazanie walorów jak i słabości tego instrumentu finansowego, wykorzystywanego coraz częściej w polskich samorządach terytorialnych. Mimo jeszcze krótkiej historii budżetu obywatelskiego w warunkach polskich można pokusić się o wyrażenie ogólnego stanowiska i sformułowanie pierwszych wniosków oceniających o charakterze syntetycznym. $Z$ jednej strony mamy do czynienia z dużym optymizmem i entuzjazmem co do jego użyteczności, z drugiej zaś pojawiają się pierwsze symptomy świadczące o jego ułomnościach. Artykuł jako całość ma charakter opisowy i przyczynkarski.

\section{Koncepcja i istota budżetu obywatelskiego}

Uczestnictwo obywateli w procesie rządzenia jest postrzegane jako podstawa demokratycznego państwa prawa. Drogą w tym kierunku jest to, co nazywa się partycypacją społeczną. Polega ona na aktywnym uczestnictwie 
obywateli w zarządzaniu sprawami publicznymi w państwie, tak na poziomie krajowym, jak i lokalnym. Chodzi tutaj o zaangażowanie się w proces podejmowania decyzji o charakterze publicznym. Ważną rzeczą jest określenie zakresu aktywności obywatelskiej.

Jej natężenie zmienia się od form mało aktywnych (konsultacje) do form rozwiniętych (decydowanie). Miejsce pośrednie zajmuje współudział obywateli w podejmowaniu istotnych decyzji ${ }^{1}$. Konsultacje społeczne nie opierają się na zasadzie partnerstwa, bowiem decyzja oraz odpowiedzialność i tak spada na władzę publiczną, które ostatecznie podejmuje decyzję w danej sprawie. Zbliżoną techniką partycypacji (bardziej kameralną) jest lobbing, obejmujący wyjaśnianie i przekonywanie do konkretnej rzeczy, w rezultacie zawierający elementy deliberacji. W pewnym stopniu można też przywołać za P. Swianiewiczem formę demonstracji oraz petycji. Wydaje się, że najpełniejszym udziałem w rządzeniu jest zatem bezpośredni wpływ obywateli na podjęcie decyzji, dotyczącej spraw publicznych. Wymiarem tym jest udział w wyborach i udział w referendach. Są to formy demokracji bezpośredniej, ponieważ trudno mówić o innym bardziej istotnym wpływie na decyzje publiczne.

Udział w projektach nazywanych budżetem obywatelskim sytuuje go raczej w obszarze współdecydowania (razem z władzą i administracją publiczną) o podziale i realizacji pewnej puli środków finansowych, mieszczących się w ramach klasycznego budżetu rocznego.

Według ujęcia Banku Światowego, budżet partycypacyjny (participatory budget) jest procesem ujawniania przez obywateli swoich żądań i projektów, którzy następnie wpływają na strukturę wydatków budżetowych poprzez dyskusje i negocjacje ${ }^{2}$. Z tej definicji, oddającej czytelnie istotę takiego budżetu wypływają dwa spostrzeżenia. Po pierwsze, identyfikacja i artykulacja interesu publicznego; po drugie, decyzje podziału środków budżetowych podejmowane poprzez procedury demokratyczne. W zbliżony sposób budżet obywatelski pojmuje B. Wampler twierdząc lapidarnie, że jest to proces racjonalnego społecznie podziału zasobów publicznych ${ }^{3}$. Za podstawowe elementy budżetu partycypacyjnego uważa się:

- określony obszar mobilizujący mieszkańców,

- sukcesywnie odbywające się spotkania mieszkańców,

1 Wbrew podziałom stosowanym w teorii komunikowania się, informowanie nie jest formą partycypacji społecznej, ponieważ występuje przekaz tylko w jedną stronę: od władzy do mieszkańca.

2 World Bank's Empowerment Case Studies: Participatory Budgeting in Brazil, strona internetowa: http://siteresources. worldbank.org/INTEMPOWERMENT/Resources/14657_Partic-Budg-Brazil-web.pdf (dostęp 25.07.2015 r.).

3 B. Wampler, A Guide to participatory budgeting, [w:] Participatory Budgeting, red. A. Shah, World Bank 2007, s. 21. 
- cykl działań odpowiadający bezpośrednio cyklowi budżetowemu,

- sieć organizacji jednostek działających na rzecz zaangażowania mieszkańców ${ }^{4}$.

Taka formuła budżetu jest szeroko wprowadzana m.in. w samorządach brytyjskich. Budżet ten daje władzom lokalnym oraz mieszkańcom możliwość wspólnego decydowania o dostarczaniu usług publicznych. Brytyjska przebudowa samorządu lokalnego zmierza do coraz większego rozwoju demokracji uczestniczącej.

W. Kębłowski za kryteria wynikające z definicji budżetu partycypacyjnego przyjmuje:

- spotkania mieszkańców,

- jasno określone środki finansowe,

- wiążący charakter,

- cyklicznośćs.

Zdaniem autora niewiele samorządów spełnia wszystkie te kryteria. Oznacza to, że większość budżetów określanych partycypacyjnymi nie jest nimi w rzeczywistości. Nawiązując do przywołanej przez autora koncepcji „prawa do miasta” kryteriami identyfikacji budżetu obywatelskiego są:

- partycypacyjne ustalenie zasad,

- decyzyjność spotkań,

- różne skale terytorialne,

- kompetencje - „twarde” i „miękkie” projekty,

- projekty i priorytety,

- nowe organy decyzyjne otwarte dla mieszkańców,

- wspólna weryfikacja, preselekcja, monitoring realizacji i ewaluacja,

- współodpowiedzialność i zauważalne efekty ${ }^{6}$.

Łatwo zauważyć, że takie pojmowanie struktury budżetu obywatelskiego staje się coraz bardziej sformalizowane, ponieważ kolejne działania mieszczą się w ramach określonych procedur, które należy podjąć i przestrzegać. Jest to zrozumiałe, bowiem odbywa się to w obrębie funkcjonowania szeroko pojętej administracji publicznej, a ona sama poddawana jest odpowiednim rygorom i reżimom (w tym finansowym, prawnym).

Budżet określany tym mianem w założeniu ma być instrumentem partycypacji społecznej w zarządzaniu sprawami publicznymi. Jego wykorzystanie jest też sposobem budowy tzw. społeczeństwa obywatelskiego. Celem budżetu obywatelskiego jest zwiększenie aktywności mieszkańców w sferze publicznej poprzez bezpośredni udział w decydowaniu o określonych sprawach miasta. Wzorem miast (prekursorem było

4 P. Neyroud, Public Participation in Policing, London 2001, s. 31.

5 W. Kębłowski, Budżet partycypacyjny. Ewaluacja, Instytut Obywatelski, Warszawa 2014, s. 13-20.

6 Ibidem, s. 21-32. 
brazylijskie miasto Porto Alegre), które zdecydowały się na takie rozwiązanie, również niektóre miasta polskie (np. Sopot) podjęły działania na rzecz przejawiania się tego typu inicjatywy publicznej.

\section{Ocena budżetu obywatelskiego z perspektywy efektywnościowej}

Praktyka funkcjonowania budżetu obywatelskiego w samorządach polskich jest krótka. Do tej pory niewiele samorządów (przede wszystkim nieliczne miejskie) zdecydowało się na wykorzystanie takiego instrumentu finansowego, choć przed ostatnimi wyborami samorządowymi (2014) na ten krok zdecydowało się coraz więcej samorządów w Polsce, również na poziomie województwa i powiatu (ok. 70 w 2013 r.). Za główne powody rozwoju budżetu obywatelskiego w kraju uznaje się:

- rosnące ambicje i aktywność mieszkańców,

- wybory samorządowe,

- korzyści dla rozwoju jednostki,

- zainteresowanie mediów,

- porównanie z innymi jednostkami ${ }^{7}$.

Narastające zainteresowanie budżetem obywatelskim zaznacza się przed zbliżającymi wyborami komunalnymi, ze względu na możliwość bezpośredniego kontaktu władzy z mieszkańcami oraz próby promocji tego rozwiązania w środkach masowego przekazu. Należy zwrócić uwagę, że wszystko to odbywa się w świetle prawa i w ramach środków publicznych (a nie z funduszy partii, czy stowarzyszeń).

W niniejszym artykule ocenę użyteczności budżetu obywatelskiego przeprowadzono na przykładzie Łodzi ${ }^{8}$. $Z$ inicjatywy prezydenta Łodzi w 2013 r. podjęto przygotowania do wdrożenia budżetu obywatelskiego na rok $2014 \mathrm{r}$. Jego istotą było wydzielenie $20 \mathrm{mln}$. zł z budżetu miasta, o których przeznaczeniu mieli decydować mieszkańcy miasta. Realizacja budżetu obywatelskiego wymaga skomplikowanej i rozbudowanej procedury postępowania. Pociąga to za sobą duży nakład czasu, zaangażowania wielu urzędników i radnych oraz znaczący koszt finansowy,

7 D. Kraszewski, K. Mojkowski, Budżet obywatelski w Polsce, Warszawa 2014, s. 4-5.

8 Jest to miasto, które przeznaczyło najwięcej środków budżetowych na ten cel (20 mln zt, w 2015 r. - $40 \mathrm{mln}$ zt). W planach prezydenta miasta do końca kadencji (2018) jest wydanie $100 \mathrm{mln}$ zł (przy budżecie ok. 4 mld zt). zamiar taki budzi zdziwienie, ponieważ z wieloletniej prognozy finansowej wynika, że w 2018 r. cały budżet inwestycyjny Łodzi będzie wynosił $232 \mathrm{mln}$ zł. 
o którym mało się mówi (m.in. wynajęcie pomieszczeń, ulotki, reklama w mediach, nadgodziny urzędników itp.).

Już na etapie procedury, kwota ta została podzielona na część ogólnomiejską i części rejonowe (byłe dzielnice). Jest to rozdrobnienie środków, ale zapewne zamiarem twórców tego budżetu było zaangażowanie możliwie jak największej liczby mieszkańców Łodzi. Część zgłaszanych przez łodzian propozycji dotyczyła spraw drobnych, mieszczących się w ramach działalności bieżącej. Pozostałe odnosiły się do niewielkich inwestycji, zamykających się w cyklu rocznym. Uzyskane w ten sposób efekty są niewielkie z punktu widzenia rozwoju miasta i zaspokajania potrzeb priorytetowych (rozwiązywanie ważnych problemów). W pierwszym rzędzie należy do nich zaliczyć poza budową infrastruktury - polepszenie tragicznych warunków mieszkaniowych, dożywianie biednych dzieci i zapewnienie opieki medycznej w placówkach oświatowych, znaczne skrócenie (z 10 lat) oczekiwania na miejsce w domach pomocy społecznej. Koncentracja środków $\mathrm{z}$ budżetu obywatelskiego chociażby na tych obszarach sukcesywnie pozwoliłaby uzyskać poprawę.

Groteskowo wygląda zgłaszanie w ramach tego budżetu, potrzeby ustawienia koszy na psie odchody, podczas gdy należy to do elementarnych obowiązków urzędników i służb miejskich. Inicjatywy obywatelskie informują o pewnych potrzebach i bolączkach życia dnia codziennego, które muszą być przedmiotem zainteresowania władz miejskich. Powstaje jednak pytanie, czy musi być to realizowane w ramach szumie reklamowanego budżetu obywatelskiego? W tym miejscu rodzi się kolejne pytanie, kto odniósł większe z tego korzyści, prezydent miasta czy mieszkańcy? Zyskiem dla prezydenta jest m.in. możliwość promowania się, a ściślej kształtowania swojego pozytywnego wizerunku, poprzez bezpośredni kontakt z mieszkańcami. Z kolei dla części mieszkańców angażowanie się w procedurę budżetową przynosi rozczarowanie, bowiem nie wszystkie propozycje, mimo że słuszne, są realizowane (np. ogrody Karskiego, uruchomienie nocnych linii). Warto zaznaczyć, że niejednokrotnie poszczególne projekty zostały źle skalkulowane, co skutkuje niedoborem środków, a następnie jedynie częścią ich wykonania. Nadto, głosowanie na zgłoszone projekty, odbywa się często przy silnym zaangażowaniu pracowników (i ich rodzin, znajomych) zatrudnionych w podmiotach, które mają przejąć efekt.

Możliwość pozyskania tą drogą chociaż niewielkich pieniędzy na sfinansowanie przedsięwzięć uznanych za potrzebne, wyzwoliło duże zainteresowanie łodzian. W konstrukcji budżetu obywatelskiego na $2014 \mathrm{r}$. wzięło udział ponad 100 tys. obywateli miasta. Taką eksplozję społecznego entuzjazmu można tłumaczyć dwojako. Po pierwsze, budżet obywatelski przy nagłośnieniu medialnym stał się nowym, modnym i atrakcyjnym instrumentem pobudzenia aktywności obywatelskiej, która do tej 
pory $\mathrm{w}$ Łodzi kształtowała się na niskim poziomie. Po drugie, wysoka frekwencja $\mathrm{w}$ poszczególnych etapach budowy budżetu obywatelskiego świadczy o braku zaufania do tradycyjnych form zgłaszania potrzeb (propozycji, problemów), tj. radnym na dyżurach, prezydentowi miasta i jego zastępcom, urzędnikom, kontaktom w ramach jednostek pomocniczych. W tym ostatnim przypadku praktyka dowodzi dość nikłej sprawności działania tych jednostek w dużych miastach.

Mieszkańców Łodzi nie informuje się o wielkości deficytu w budżecie, całkowitym zadłużeniu miasta, kosztach obsługi długu, zachęca się ich zaś do wydawania coraz większych środków budżetowych (w 2014 r. $20 \mathrm{mln}$., w 2015 r. - $40 \mathrm{mln}$. i docelowo w 2018 r. - $100 \mathrm{mln}$. zł). Wydaje się, że w takim postepowaniu kryje się głęboka sprzeczność, ponieważ być może świadomość mieszkańców o złej sytuacji finansowej miasta pociągnęłaby za sobą pewne zbiorowe wyrzeczenia, a nie życie na kredyt. Należy podkreślić, że koszty ponoszenia wydatków powinny pozostawać pod kontrolą i być akceptowane przez obywateli miasta. Taka sytuacja nie ma miejsca $\mathrm{w}$ Łodzi, a zbyt duży ciężar kosztów będą ponosić przyszłe pokolenia.

Wiele samorządów nie do końca rozumie istotę tego budżetu i popełnia dwa istotne błędy. Podejmowane są bowiem działania mieszczące się w ramach działalności bieżącej realizacji zadań, zamiast w działalności inwestycyjnej, w której chodzi o wskazanie najpilniejszych potrzeb z punktu widzenia mieszkańców. Takie postępowanie prowadzi często do rozproszenia i tak skromnych środków finansowych (propozycje obejmują każdy obszar jednostki). Stosowana w Polsce wersja budżetu obywatelskiego zdecydowanie wymaga modyfikacji w kierunku przygotowania propozycji zadań wraz z kosztami dla mieszkańców, którzy dokonają wyboru. Wydaje się, że zgłaszanie propozycji zadań przez mieszkańców, a następnie ich weryfikacja przez administrację (gdyż niektóre z nich są nierealne z przyczyn prawnych, technicznych, finansowych) jest nie tylko czasochłonne, ale też dość kosztowne.

\section{Podsumowanie}

Obserwacja działań związanych z konstrukcją tego typu budżetu skłania do stwierdzenia, że stał się on niejako modą i techniką pogłębiania procesów partycypacji społecznej. Łatwo spostrzec, że to wszystko o czym się mówi i robi w ramach budżetu obywatelskiego, nie jest $\mathrm{w}$ istocie takim budżetem! Budżet to inaczej plan finansowy, obejmujący stronę do- 
chodów i wydatków. Aktywność mieszkańców w obrębie budżetu obywatelskiego skupiona jest tylko na wydatkowaniu publicznych pieniędzy na cele, które zwyciężyły w głosowaniu. Zdecydowanie razi, jeśli cele te polegają na realizacji rzeczy należących do działalności bieżącej miasta, np. ustawienie koszy, naprawa chodnika, spowolnienie ruchu kołowego, posadzenie drzew lub krzewów, czy ich przycięcie. Do przyjęcia są natomiast propozycje polegające na zmianie zagospodarowania przestrzeni publicznej w sposób bardziej przyjazny lub bezpieczny dla mieszkańców w najbliższym otoczeniu. Należy zdawać sobie sprawę, że tego typu przedsięwzięcie wymaga nieco dłuższego czasu niż jeden rok. W gruncie rzeczy tak pojmowany budżet obywatelski uczy wydawania środków publicznych pomiędzy konkurencyjne cele.

Jeśli mowa o rozwiązaniu w kategoriach budżetu obywatelskiego to trzeba wiedzieć, że na ogół mamy do czynienia z małymi projektami dotyczącymi zamierzeń inwestycyjnych i spraw bieżących. Ograniczeniem tego jest bowiem cykl jednoroczny - budżetowy. Trzeba przy tym pamiętać, że budżet $\mathrm{w}$ rozumieniu przedmiotowym jest procesem najpierw gromadzenia środków, a następnie ich rozdysponowania. Pozyskanie pieniędzy jest znacznie trudniejsze niż ich wydawanie, o czym na ogół nie wiedzą lub nie chcą wiedzieć polscy politycy. Ci ostatni lubią bardziej zajmować się podziałem ograniczonych zasobów finansowych aniżeli ich zdobywaniem. Jest to oczywiste $\mathrm{z}$ dwóch powodów. Po pierwsze, oznacza to szybkie decydowanie, a po drugie, stanowi oczywisty atrybut władzy.

Reasumując, można powiedzieć, że budżet obywatelski angażujący czas i energię tylko pewnej części obywateli, z punktu widzenia ekonomicznego stanowi formułę nieefektywnego gospodarowania środkami pieniężnymi, będącymi własnością publiczną. Przesądza o tym omówiona procedura prowadząca do utraty efektów skali. Jeśli z kolei przyjąć, że budżet partycypacyjny uczy zaangażowania społecznego w porządku demokratycznym - to okazuje się on ceną, jaką trzeba zapłacić za zastosowanie tego rozwiązania finansowego. W takim przypadku znów mamy do czynienia z kolizją elementów ekonomicznych i elementów społecznych, rozstrzyganą na korzyść tych ostatnich.

Kończąc, można spojrzeć na budżet partycypacyjny z innego punktu widzenia. Dotychczasowa mnogość zgłaszanych propozycji obywatelskich (nawet ponad 700) nie służy niczemu dobremu, gdyż angażuje zbyt wiele osób i czasu w celu przeglądu, analizy oraz sporządzenia listy możliwych do wykonania projektów. Ograniczony czas sprawia, że wkrada się pośpiech, który skutkuje niejednokrotnie bardzo powierzchownym szacunkiem kosztów. Niedoszacowanie projektów obywatelskich powoduje, że często zawężany jest zakres rzeczowy przedsięwzięcia (np. realizuje się jedynie połowę parkingu). Wypacza to, a nawet ośmiesza ideę budżetu obywatelskiego, ponieważ, aby dokończyć projekt, trzeba dzielić 
zamówienie (projekt) i uruchomić odpowiednie procedury w następnym roku. Powstaje zatem pytanie, czy na tym polega budżet obywatelski?

Możliwe jest nowe podejście do tego zagadnienia. To urzędnicy powinni przygotować wykaz zadań bieżących i inwestycyjnych (np. maksymalnie do $20 \mathrm{w}$ dużych miastach), mieszczących się w większych pulach finansowych. Niektóre z nich, z uwagi na zakres i charakter mogą być określone do realizacji w cyklu dwuletnim. Dopiero w tym momencie otwiera się pole do aktywności mieszkańców, polegającej na debacie publicznej, a następnie wyborze priorytetowych zadań. Taki sposób postępowania zapewnia większą racjonalność ekonomiczną i społeczną w wydatkowaniu środków budżetowych. W trakcie dyskusji, jej uczestnicy mogą zgłaszać nowe propozycje do rozważenia i wcześniejszego przygotowania.

\section{Bibliografia}

Dolewka Z., Budżet partycypacyjny $w$ teorii $i$ w praktyce, Wydawnictwo Uniwersytetu Ekonomicznego we Wroctawiu, Wrocław 2015, Biblioteka Regionalisty.

Kraszewski D., Mojkowski K., Budżet obywatelski w Polsce, Warszawa 2014.

Neyroud P., Public Participation in Policing, London 2001.
Wampler B., A Guide to participatory budgeting, [w:] Participatory Budgeting, red. Shah A., World Bank 2007.

World Bank's Empowerment Case Studies: Participatory Budgeting in Brazil, http://siteresources. worldbank. org/INTEMPOWERMENT/Resources/14657_Partic-Budg-Brazil-web. pdf. (dostęp 25.07.2015) 